\title{
Management of e-waste
}

\author{
Janet Joseph
}

\begin{abstract}
The sky rocketing growth in various industries were being witnessed due to the rapid advancement in technologies and innovation in a very short duration of time. A large percentage of the population had the capacity to change or replace appliances and gadgets with the new ones launching into the society. This resulted in discarding of the former equipments before reaching it's end of life duration. Since industries designed and manufactured goods on a large scale, as a result, a lot of manufacturing industries especially those that manufactured electrical and electronics were expelling a lot of waste to the environment. These were the unsold goods and whose market values had dropped due to the newer products taking their place. This not only harmed the disposal grounds but also posed a serious risk to its components like flora, fauna and human beings as well. The paper discussed in brief, about the various steps and procedures that were undertaken to tackle the problem of e-waste management. Countries like Australia had policies implemented to be followed for the sake of waste management. Lastly, the real-life examples of few countries reflecting on how they shed light on issues when it comes to managing their respective wastes along with future predictions and estimations of e-waste.

Key words: e-waste management, recycle, electrical and electronic equipments (EEE)
\end{abstract}

\section{INTRODUCTION}

With the growing expansion in population, a more sophisticated lifestyle is being demanded. Therefore, a spark in advancement in the technology is seen from the previous years. The information and communication technologies are rising at a high rate which results in invention, manufacturing and production of electronics and electrical gadgets and products. As a result of this, a lot of electronics that are already owned and in working condition are being dumped into the disposal grounds in order to match the technological growth (Moletsane and Venter 2018). According to the Global e- waste Monitor 2014, the top three Asia-Pacific countries that generate the largest amount of e-waste are China with 6Mt., Japan showcasing 2.2Mt and followed by India with almost1.7Mt [2]. The electrical and electronicindustries use 100 percent indium, 22 percent mercury, 44 percent of copper, 50 percent tin and 34 percent of silver are mined globally every year [29]. These contribute to the streams of e-waste that are generated from the factories that manufacture electronics and also from mining regions. The e-wastes not only consist of such toxic substances that are harmful to the surrounding environment and its components but it's inappropriate way of dumping with low technology recycling enterprises result in additional serious pollutants like polychlorinated dibenzo-pdioxins and dibenzofurans (PCDD/Fs), polybrominated dibenzo-p-dioxins and dibenzofurans (PBDD/Fs) and other heavy metals [23].

Revised Manuscript Received on February 08, 2020.

* Correspondence Author

Janet Joseph*, Masters of Environmental Engineering and Pollution Control, Griffith University, Brisbane, Australia. E-mail: janetjoseph03@gmail.com

(c) The Authors. Published by Blue Eyes Intelligence Engineering and Sciences Publication (BEIESP). This is an open access article under the CC BY-NC-ND license (http://creativecommons.org/licenses/by-nc-nd/4.0/)
The main objective of this research paper is to look into the different characteristics of e-waste, the current measures and steps being practiced for e-waste management, real life illustrations, challenges being faced and future research scopes.

\section{A. Definition of e-waste}

E-wastes can be characterized as the waste that is produced from the electronics and electrical manufacturing industries. The Waste Electronic and Electrical Equipment (WEE) Directive of the European Union defines electronic and electrical equipment as a gadget that utilizes current and an electromagnetic field to operate and include that gadget for generation, transfer and measurement of such currents and fields [22]. This definition applies for those equipments whose voltage ratings are not more than 1000 volts for alternating current (AC) and 1500 volts for direct current (DC).

The Central Pollution Control Board of India explains ewaste as wastes that are generated from used electronic devices and gadgets from household appliances that are no more fit to be used or are unfit for their standard use and are ordained for either recycling, reusing or demolition. Such devices include computers, cellphones, hair dryers, refrigerators, washing machines, dishwashers etc. [4]

\section{E-WASTE GENERATION}

Even though large-scale e-wastes like refrigerators, cellphones and computers are being discarded, it is the accelerated advancement in information technology that gives way to a lot more of the e-wastes. Due to the persistent demand for new, efficient and effective technology, the life span of electronics is becoming shorter and shorter becoming a part of the e-waste. Life span here points to the interest in usage by the user. They are discarded way before they become unproductive. 'Solving the E-waste problem (StEP)' estimates that the world will produce about 33 million tonnes of waste in the coming years and almost 72 million tonnes of waste by 2017 with China contributing 12.2 million tonnes and followed by US giving out 11 million tonnes of e-waste [9]. Yet another report produced by The Associated Chambers of Commerce of India (ASSOCHAM) highlighted the fact that the e-waste being generated in India will be accelerated in the coming years from 12.5 lakhs metric tonnes to a level upto 15 lakhs metric tonnes per annum. The major e-waste contributing cities in India will be Mumbai, Delhi, Kolkata, Chennai, Bengaluru, Hyderabad and Pune [20]. The production and manufacturing of e-waste will continue to increase due to the rapid advancement in technology and designs.

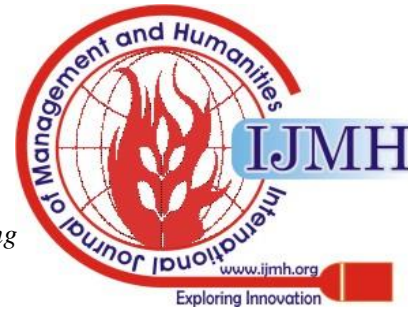


The electronics and electrical industry is one of the fastest developing industry together with the high affordability levels of the consumer, the currently used electronics and electrical goods are disposed. This raises serious concerns about the management of e-waste in different countries [9]. The United Nations Environmental Program (UNEP) mentioned in its report about the generation of e-waste that has increased upto 50 million tonnes causing health and environmental concerns whereas, in China about 5 million tonnes of personal computers exclusively put the surrounding environment to risk.[7]

As per the studies conducted, it is observed by the researchers that the developing countries contribute more to the e-waste stream as compared to that of the developed countries. The developing countries produce about double the current generated e-waste by 2018. It is also forecasted that the developing countries will dispose off 400-700 million obsolete computers and 200-300 million computers by the developed countries by the end of 2030 [34].

\section{A. Impact on GDP}

For the efficient working of economies of any country, the working of computers and electrical goods is highly necessary. Therefore, with the increasing economy of a country, the usage of computers and other electronic and electrical goods increase and this results in high number of gadgets and equipments in e- waste streams [26]. Countries like Eastern Europe, China, Latin America and India are developing countries, meaning their economies have a significant growth rate which would make them the top ewaste generators in the next 10 years.

With the increase in population in developing countries, they as well, contribute to the e-waste streams. The rapid advancement in technologies, designs and software will not be supported by the current systems of electronics and electrical equipments. Therefore, to harmonize with the newer technologies, the older ones are put to thrash contributing to the e-waste stream.

Again, the economy of the country is being utilized in managing and controlling of the e-waste generated by each city in the country. This way, the quantity of e-waste streams can greatly affect the GDP of the country if not taken care in a proper manner.

\section{CONSTITUENTS OF E-WASTE}

The structure of e-waste mainly depends upon the age and type of the junk. For instance, the e-wastes from electronic products contain more quantity of metals as compared to the e-wastes generated from household gadgets [35].

There are more than 1000 materials that are categorized either as hazardous or non-hazardous waste. They constitute of plastic, ferrous metals, non-ferrous metals, printed circuit boards from different electronic goods like television, cellphones etc., rubber and other items. E-wastes include more than 50 percent of iron and steel, followed by plastics constituting about 21 percent of the total waste stream. Ferrous metals involve the presence of silver and gold whereas non-ferrous metals contain traces of aluminium and copper [38].

A typical mobile phone is made up of 40 different metals and non-metals that includes copper, silver, tin, indium, lithium, cobalt and others. Apart from these, the phone also consists of plastic and ceramic elements [15]. About 23 percent of the weight of the cellphone is that of the metals.
If the battery of the phone is also taken into account then the proportionality of metals would be higher as compared to the non-metals [12].

With the advancement in technology, the sophistication of the products also increases. Hence, the demand for more and more precise metals and non-metals is at its peak. Therefore, Premalatha, M. and others state that electronics and electrical industries constitute the 80 percent for indium demand globally, 80 percent for ruthenium and 50 percent of antimony [26].

Apart from these, the environmental degradation that occurs due to the mining processes of very precious metals and non-metals are huge due to their sparse existence. To procure $1 \mathrm{~kg}$ of gold or platinum, around 10,000 tonnes of carbon dioxide is emitted into the atmosphere giving rise to global warming. The cumulative productions of Carbon dioxide gas from all the metal production industries is calculated to be around 23 million tonnes, which is $1 / 1000$ of the global emissions.

Various chemicals found in e-wastes are hazardous to health as well as to the receiving environment [28]. Although recycling is done before the disposal, yet a huge quantity of chemicals is carried to the disposal grounds causing pollution and danger to the surrounding environment.

waste encompass polybrominated diphenyl ethers (PBDEs) that are flame retardants and are mixed with plastic and other components. They do not bond with plastics and so leach out into the receiving environment[5]. PBDEs being lipophilic in nature, bioaccumulate into the organisms and therefore, exhibit their presence all throughout the food chain.

Similarly, refrigerators and air conditioners that are dumped way before they become unfit to use contain chlorofluorocarbons (CFCs) and are released into the atmosphere disturbing the ozone layer in the stratosphere [32].

One of the major challenges is to formulate different steps to manage e-waste. It is due to the rapid change in technology, rapid changes in composition of gadgets is seen which results in less time for strategy fixation. For instance, the TV or computer monitors that consisted of CRTs had Pb in it [27], are replaced by flat LCD screens. But this advantage is negated by the fact that LCDs contain Hg along with $\mathrm{Zn}$, Sn and In [17]. Therefore, the steps for recycling and methods of disposal should be checked and made suitable and favourable changes in accordance with the change in composition of the e-waste.

\section{ENVIRONMENTAL IMPACT}

In developing countries, where the e-wastes are burnt or recycled in an informal way leads to contamination of the surrounding environment. This not only includes the land and the soil but also the water bodies, air, human beings and other creatures that exist. Few of the impacts on water, air, land and human beings are being discussed below.

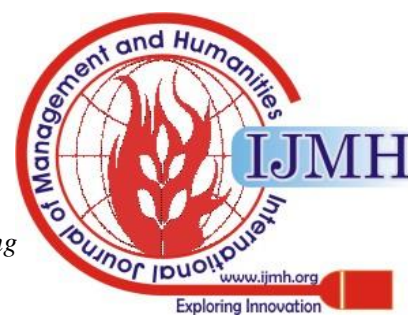




\section{A. Polluted Water Bodies}

The leachates present in e-waste that are dumped at the sites pollute the water bodies [37]. PDBEs and PCBs were detected in high concentration levels in about 90 percent of the fish samples taken from the nearby water body and also it affected the food chain due to its lipophilic nature. The increased levels of concentrations of PDBEs and PCBs in organisms tested near recycling units and organisms away from the recycling units suggest that the rise in concentration levels is due to the present activities and measures followed to recycle the e-waste. This bioaccumulation of the chemicals not only polluted the river but also the food chain as the fish were a source of food to human beings and other land creatures.

Heavy metals like lead are a part of e-waste. Their concentration more than 500ppb in water bodies can lead to inhibition of enzymes that are required for the process of photosynthesis. If this process is slowed down, there is no algae growth possible which affects the organisms and animals that feed on water plants. In this way, the entire food chain is affected adversely [13]. The acute effects of Lead are reported on invertebrates and other organisms when the concentration levels of lead are about 100 to 1000,000 $\mu \mathrm{g} / \mathrm{L}$ [19].

\section{B. Polluted Air}

The improper steps to burning of e-wastes produce fumes that pollute the environment. The atmosphere where the recycling sites are located consists of high levels of halogenated flame retardants (HFRs) as compared to sites where the recycling units are not located [26]. This reveals the fact that e-waste recycling and industrial activities are sources of air pollution.

The human beings especially the workers and people in and around the location that emit flame retardants are affected adversely. The changes that are witnessed include reduced IQ levels, alternative timings of puberty and breast cancer among women [21]. The researchers also reported that the level of fire retardants was seen rising upto 63 percent in the atmosphere where 30 percent of the particles were in the respirable form (less than $3 \mu \mathrm{m}$ ).

Also, the mining of different minerals like precious metals and non-metals required for the manufacturing of different equipments for their sophisticated working requires a lot of energy for their extraction. Hence, a lot more CO2 emissions are witnessed by the mining sites and the surrounding regions.

\section{Polluted Lands}

High concentrated levels of PCBs and PBDEs have been seen in areas where the recycling units and sites are located[8].The soils contained high levels of PAHs which affected the vegetation. The PAHs got bioaccumulated into the vegetation and were consumed by humans and other creatures. The average intake of carcinogenic PAH was estimated to be $108 \mathrm{ng} / \mathrm{kg} /$ day which indicates that the vegetation grown near the recycling units should be avoided to lower or abolish the levels of PAH intake. The high levels of these chemicals not only affected the food chain but also the healthy growth of the vegetation.

Processes like mining, smelting and recycling of e-waste ruin the fertility of the ground soil making it unfit for agricultural and grazing purposes which leads to risks of food security and human health. Zhang and his team reported that the concentration levels of Lead on the grounds of China was about $35.9 \mathrm{mg} / \mathrm{kg}$ by weight during 2013 and gradually increased by 30 percent due to increased transportation and industrial activities in the region [39].

\section{Human Tissues}

The accumulation of heavy metals especially $\mathrm{Pb}$ and $\mathrm{Cd}$ at high concentration levels affect the normal working of the human body. Children at Guiyu showed signs of difficulty in respiration due to $\mathrm{Pb}$ and $\mathrm{Cd}$ poisoning [33].

Even though fine particulate matter, dust particles and smoke do not cause respiratory malfunctioning, but lead to eye, skin, throat and nose irritation [36].

Food is considered to be the riskiest source of exposure to the heavy metals to the human body. The food kept at the open-air food markets are endangered due to the presence of heavy metals in the atmosphere. The food that is kept open on newspapers or in buckets are easily contacted with the dust particles and the heavy metals in the atmosphere [16]. Moreover, the risk of getting sick or any serious illness is higher in children below 18 years of age as compared to the adults. This is due to the lesser body weight seen in children.

$\mathrm{Li}$ reported the concentration of polybrominated diphenyl ethers in umbilical cord tissues by the process of gas chromatography and mass spectrometry [18]. They found out that mothers that were exposed to polybrominated diphenyl ether had five times the normal levels of polybrominated diphenyl ethers. 697 proteins were deferentially expressed through proteomic analysis. Antioxidant imbalance and cell apoptosis was also seen and reported.

\section{CURRENT MEASURES TAKEN TO MANAGE E- WASTE}

There are certain issues that are to be mainly focused on in order to conclude the steps or measures to be undertaken for management of e-waste. They are as below:

a) To scale down the generation of e-waste.

b) To encourage cleaner production at every stage of manufacturing and production process.

c) To advance the technologies that are available for the treatment and disposal of e-wastes.

\section{A. EPR}

Keeping the above points in mind, the Extended Producer Responsibility (EPR) concept has been developed. This concept of life cycle assessment not just looks into the functioning and discarding of the product, but also sheds light on the entire life-cycle of the product right from its extraction, manufacturing, production, utilization and finally the dumping of the product. According to [24], EPR is defined as the environmental policy that every industry is bound to follow and it's their sole responsibility to look after the product during it's post-consumer period until the final disposal.
Eyes Intelligence Engineering \& Sciences Publication

(C) Copyright: All rights reserved.

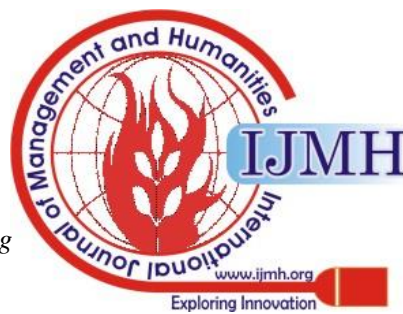


The EPR was first established in Germany in 1991. The main motive behind this policy was to provide the industries with incentives such that the industries design products that are environmental friendly [24]. As the name suggests, the responsibility of the industries is not limited to just look into the emissions released due to the mining and manufacturing processes but also focus on the after-use period of the product and take suitable steps for proper disposal or recycling so as to reduce wastes and management costs (Hemalatha et al 2014). For instance, the industries are supposed to design products that consume less energy and resources, generate less waste and rather than disposing supports another concept known as circular economy.

\section{B. Recycling Practices}

According to the consumer behaviour and the interests of the local market, the recycling regulations for the e-waste have been implemented in several countries. Canada has developed it's own recycling and processing units which are practicing the e-scrap policy with a target of 17 percent by 2018. Africa has no formal legal rules for recycling it's ewaste stream. The country reuses the imported electronics upto 85 percent. Europe has it's strategies formed where each country follows it to recover at least 85 percent of the products. Taiwan recycles 82 percent of it's e-waste stream.

As e-waste consists of large amount of substances, it is considered to be a secondary source. Lots of substances can be procured from the e-waste if carefully handled and processed before the final disposal. Biotechnological approaches like hydrometallurgy and pyrometallurgy are considered to be two of the best options available to produce an environmentally friendly procedures for the treatment of e-wastes. Hydrometallurgy is a process where an aqueous solution is used for the recovery of metals from ores or various hydrometallurgical processes available out of which leaching is best suited for the recovery of metals from ewaste stream [3]. Whereas, the process of pyrometallurgy involves the use of high temperatures for either purification or extraction of the useful metals [1]. Cyanogenic organisms like Pseudomonas fluorescens have absolute applications for the bioleaching of metals especially precious metals like gold from the e-waste (Garlapati 2016).

\section{CASE STUDIES}

\section{A. India}

India being a developing country has majority of it's population being poor or below poverty line (BPL). The electronics industry is one of the fastest growing industries in India. Most of the e-wastes are handled and recycled in a proper manner in major cities like Mumbai and Delhi whereas the places that are yet to see developments. The recycling and handling of e-wastes are done by this poor or the BPL class people who turn to be uneducated. Therefore, most of them are unaware of the dangers and problems that will arise due improper or careless handling of different operations. Since there is a lack of information among such operated by the electronic industries. Brazil started

\section{Biotechnological Approach} concentrates, recycled or discarded materials. There are

people, they are prone to health hazards as well as pose a danger to the surrounding environment.

Keeping all in this in view, the government body named Central Pollution Control Board implemented certain guidelines for a healthy environment and an excellent waste management in the country. Alongside, the Ministry of Environment and Forest developed rules and executed the E-Waste Rule in the year 2011 which later came into force by 2012. This rule clearly sheds light on the responsibilities including that of the producer, the collection centres, customers, dismantling units and the recycling units. The rule worked according to the EPR system where the producer is the sole responsible person for collecting and financing of systems.

The Associated Chambers of Commerce of India (ASSOCHEM) reported that the e-waste in India grows at a rate of about 25 percent every year and will reach about 3.3 million tonnes of waste generated from the country by 2020 [25].

\section{B. Pakistan}

Pakistan does not hold any current data or information about it's waste production. Various rules and policies have been implemented for the protection of it's environment which include the National Environmental Policy (2005), Pakistan Environmental Protection Act (1997), Import Policy Order (2016) and various others[14]. The policies prohibit the importing of the e-wastes that are being produced by developed countries. However, these wastes still find their way to enter the country posing as a secondary substance. The Environmental Protection Act looks after the protection of the environment as well as the displacement of wastes and chemicals within or inflow and outflow from the country. Since, the country did not come up with any proper mechanism for the managing of wastes, the general public manage it locally. Burning of wastes openly or dumping the wastes is one of the common practices in Pakistan. This leads to severe health issues among the locality as well as damage to the environment.

A study that was conducted during 2014 revealed that Pakistan produced 95,000 tonnes of e-waste which primarily constituted of computers on an average every year [14].

\section{Australia}

The e-waste data information collection or retrieving is seen as a huge task for the country. Hence, not much accurate data is available about the waste generated or produced from various sources. Various policies and strategies have been enforced in order to control and manage the e-wastes being generated. Those include Product Stewardship Act 2011, Product Stewardship Regulations 2011, National Television and Computer Recycling Scheme 2011, National Waste Policy 2009 among others.

These policies allow access to the small enterprises and local household people to recycle e-waste especially televisions and computers. The industries that manufacture electronics are responsible to fund their collection centres as well as the recycling units.

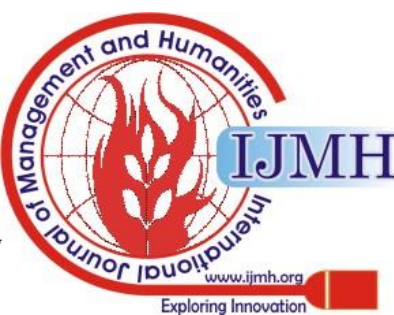


These are enforced in order to increase the recycling rates of the electronics being dumped from 17 percent in 2010 to 80 percent of recycling by 2022[10].

The Australian Bureau of Statistics in 2013 estimated that the number of electronic gadgets especially the computers and televisions that were being disposed off at their useful stage is expected to see a rise upto 44 million entities by 2028 (Commonwealth of Australia 2014).

Golev and Corder researched in order to quantify the metal values that are present in various electronics especially the ones that are being dumped [10]. The study revealed that metal value of US\$ 370 million worth was being retrieved where the printed circuit boards contributed the maximum value for metals [11].

\section{Turkey}

Turkey, a Eurasian country is facing rapid developments and expansions in technology and therefore, the industries rise in the competitive world. The main hazardous waste streams are contributed by the industrial metal manufacturing industries and the medical wastes that are disposed off from different institutions like research centres, clinics, Research and Development centres, hospitals, medical colleges and others. The Turkish Environmental Law standardized the hazardous waste. Various provisions like hazardous waste management, the excessive use of chemicals i.e., beyond the proposed limits, breaching or violation of rules result in penalties. As per the law, MoEF was held responsible for the legislation of rules and regulations as well as penalize those who break the law. The waste generated from manufacturing industries followed the end-of-pipe treatment rather than getting recycled or reused. This put a lot of burden on the natural resources which is limited. This also resulted in loss of materials, excessive labour, time and energy. It was important for the law to come up with environmentally friendly techniques to tackle the wastes generated. The European Union (EU) came up with the following strategies to be followed by the manufacturing industries:

- Regulation on burning of wastes (2010),

- Regulation on landfill of wastes (2010),

- Regulation on waste oils (2008),

- Regulation on control of hazardous wastes (2005) and

- Regulation for control of medical wastes (2005).

Sahanand others stated in their report that the generation of e-waste had been increased upto 3 to 5 percent every year more than the generation of the municipal waste [30]. The latest researches proved that the electronics waste constitute to be 7 percent of the total municipal waste with developed countries contributing no less than 8 percent. As per the data gathered from the Turkish Ministry of Environment and Urban Planning, about 540,000 tonnes of e-waste are being produced by the country every year.[6] The Regional Environmental Centre (REC) reports that only about 1 percent of the e-waste in Turkey was being recycled by the recycling units while the rest of the e-wastes were being either dumped or burnt openly causing health issues as well as damage to the environment [31].

\section{CONCLUSION}

The problem of e-waste streams was rising with the advancement in technology and the demand for more sophisticated systems resulted in dumping of current electronics into the disposal grounds before the end of life span of the product. The main source of such e-waste is industries that manufacture and produce products that utilize current, voltage or induce magnetic field. Such products are made out of metals and non-metals that pose a serious problem to the environment if not disposed off in a proper manner. With the advancement in technology, the systems become more sophisticated and so demand for more and more precise metals and non-metals. Therefore, precious metals come into role that fit perfectly to the intended use. These precious metals are not available in abundance like other metals and hence consume a lot more energy for the extraction. This emits a lot of $\mathrm{CO} 2$ into the atmosphere, polluting the surrounding land, water and air.

On the other hand, there is an immense research being done in the field of management of e-waste. The steps to cope with the rapid changing of technology and disposal of the old equipments. Various measures and technologies to suit the recycling and reusing of the dumped gadgets as per their characteristics and properties. This way, we can reduce the e-waste streams and help keep the surrounding environment healthy and clean.

The developing countries like India are still on the very initial step of recognizing the hazardous waste streams being produced. The legislation and technology are yet to be implemented for which the industries have to work out voluntarily.

\section{REFERENCES}

1. Australian Oxford Dictionary 2004, Oxford University Press, eISBN:9780191735059, https://www.oxfordreference.com/view/10.1093/acref/978019551796 5.001.0001/acref-9780195517965

2. Balde, C, Wang, F, Kuehr, R, Huisman, J 2015, 'The Global E-waste Monitor -2014, United Nations University, IAS-SCYCLE, Bonn, Germany.

3. Bhargava, S, Pownceby, M and Ram, R 2017, 'Hydrometallurgy' pp 9-11.

4. Central Pollution Control Board. (2008). Guidelines for environmentally sound management of e-waste. Ministry of Environment \& Forests Central Pollution Control Board, New Delhi. Available at: http://moef.nic.in/divisions/hsmd/ guidelines-ewaste.pdf.

5. Deng, W, Zheng, J, Bi, X, Fu, J and Wong, M 2007, 'Distribution of PBDEs in air particles from an electronic waste recycling site compared with Guangzhou and Hong Kong, South China', Environment international, vol 33, no. 8, pp. 1063-1069, via https://doi-

org.libraryproxy.griffith.edu.au/10.1016/j.envint.2007.06.007

6. European Commission Environment, 'Study on Collection Rates of Waste Electrical and Electronic Equipment (WEEE)'via http://ec.europa.eu/environment/waste/weee/pdf/Final_Report_ Art7_publication.pdf

7. European ParliamentDirective 2012/19/EU of the European parliament and of the Council of 4 July 2012 on waste electrical and electronic equipment (WEEE)Off J Eur Union, L197 2012, pp. 38-71.

8. Gao, S, Wang, J, Yu, Z, Guo, Q, Sheng, G and Fu, J 2011 , 'Hexabromocyclododecanes in surface soils from e-waste recycling areas and industrial areas in south China: Concentrations, diastereoisomer- and enantiomer-specific profiles, and inventory', Environmental Science and Technology vol 45, no. 6, pp.2093-2099, via $\quad$ https://pubs-acs-

\section{Published By:}

Blue Eyes Intelligence Engineering

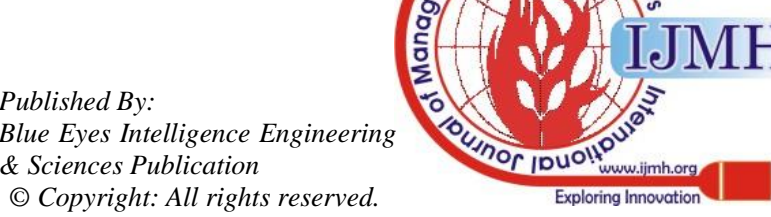


org.libraryproxy.griffith.edu.au/doi/10.1021/es1033712

9. Garlapati, V 2016, 'E-waste in India and developed countries: Management, recycling, business and biotechnological initiatives', Renewable \& sustainable energy reviews, vol 54, pp. 874-881, via https://doiorg.libraryproxy.griffith.edu.au/10.1016/j.rser.2015.10.106

10. Golev, A and Corder, G 2017, 'Quantifying metal flows in e-waste in Australia: The value chain perspective' Minerals Engineering vol 107, pp. 81-87.

11. Goleve, A, Schmeda-Lopez, D, Smart, S, Corder, G and McFarland, E 2016, 'Where next on e-waste in Australia?' Waste Management vol 58, pp. 348-358, via https://doiorg.libraryproxy.griffith.edu.au/10.1016/j.wasman.2016.09.025

12. Hageluken, C, and Meskers, C, 2008, 'Mining our computers opportunities and challenges to recover scarce and valuable metals from end-of-life electronic devices.' In: Reichl, H., et al. (Eds.), Electronics goes green 2008 pp. 623-628. Fraunhofer IRB Verlag: Stuttgart, Germany.

13. Huang, J, Nkrumah, P, Anim, D and Mensah, E 2014, 'E-waste disposal effects on the aquatic environment: Accra, Ghana', Reviews of Environmental Contamination and Toxicology, vol 229, pp. 19-34, via

https://link-springercom.libraryproxy.griffith.edu.au/chapter/10.1007\%2F978-3-31903777-6 2\#citeas

14. Imran, M, Haydar, S, Kim, J, Awan, M and Bhatti, A 2017, 'E-waste flows, resource recovery and improvement of legal framework in Pakistan', Resources, Conservation and Recycling, vol 125, pp 131 138 , via

15. Izatt, N, Izatt, S and Bruening, R 2012, 'Green procedure for the selective recovery of precious, specialty, and toxic metals from electronic wastes.', via https://ieeexplore-ieeeorg.libraryproxy.griffith.edu.au/document/6360557

16. Leung, A, Duzgoren-Aydin, N, Cheung, K, and Wong, M 2008 , 'Heavy metals concentrations of surface dust from e-waste recycling and its human health implications in Southeast China', Environmental Science and Technology, vol 42, pp. 2674-2680, via https://doiorg.libraryproxy.griffith.edu.au/10.1021/es071873x

17. Li, J, Duan, H, and Yuan, W 2009, 'Case study of a Suzhou pilo project on the suitable treatment technology for scrap computers in China.' 2009IEEE International Symposium on Sustainable Systems and Technology, ISSST '09 in Cooperation with 2009 IEEE 5156714

18. Li, M, Huo, X, Pan, Y, Cai, H, Dai, Y and Xu, X 2018, 'Proteomic evaluation of human embilical cord tissue exposed to polybrominated diphenyl ethers in an e-waste recycling area', Environment International, vol 111, pp 362-371, via https://doiorg.libraryproxy.griffith.edu.au/10.1016/i.envint.2017.09.016

19. Mager, E, Brix, K, Gerdes, R, Ryan, A and Grosell, M 2011, 'Effects of water chemistry on the chronic toxicity of lead to the cladoceran, Ceriodaphniadubia', Ecotoxicology and environmental safety,vol 74, no 3, pp 238-243, via https://doiorg.libraryproxy.griffith.edu.au/10.1016/j.ecoenv.2010.11.005

20. Nisa, M 2014, 'E-Waste Management', Nano science Nanotechnology, vol 2, no.1, pp. 766-768.

21. Nguyen, L, Diamond, M, Venier, M, Stubbings, W, Romanak, K, Bajard, L, Melymuk, L, Jantunen, L and Arrandale, V 2019, 'Exposure of Canadian electronic waste dismantlers to flame retardants', Environmental International, vol 129, pp. 95-104, via https://doi-

org.libraryproxy.griffith.edu.au/10.1016/j.envint.2019.04.056

22. Nnorom, I, Osibanjo, O and Nnorom, S 2007 'Achieving Resource Conservation in Electronic Waste Management: A Review of Options Available to Developing Countries', Journal of Applied Sciences, vol7, no. 20, pp. 2918-2933,

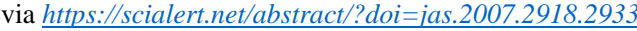

23. Ogunseitan, O, Schoenung, J, Saphores, M and Shapiro, A 2009 'The Electronics Revolution: From E-Wonderland to EWasteland', Science, vol326, no. 5953, pp. 670-671, via $h t t p s: / / s c i e n c e-s c i e n c e m a g-$ org.libraryproxy.griffith.edu.au/content/326/5953/670

24. Organization for Economic Cooperation and Development, 2001. Extended producer responsibility. A guidance manual for governments.

http://www.oecd.org/env/environmentalpolicytoolsandevaluation/extendedproducerresponsibility.htm

25. Pathak, P, Srivastava, R and Ojasvi 2017, 'Assessment of legislation and practices for the sustainable management of waste electrical and electronic equipment in India', Renewable and Sustainable Energy org.libraryproxy.griffith.edu.au/10.1016/j.resconrec.2017.06.015 International Symposium on Technology and Society, ISTAS, article

Reviews, vol 78, pp 220-232, via https://doiorg.libraryproxy.griffith.edu.au/10.1016/j.rser.2017.04.062

26. Premalatha, M, Abbasi, T, Abbasi, T and Abbasi, S 2014, 'The Generation, Impact, and Management of E-Waste: State of the Art', Critical Reviews in Environmental Science and Technology, vol 44, no. 14, pp. 1577-1678, via https://www.tandfonline.com/doi/abs/10.1080/10643389.2013.782171

27. Puckett, J, Westervelt, S, Gutierrez, R and Takamiya, Y 2005, 'The digital dump. Exporting re-use and abuse to Africa.' Report from the Basel Action Network, Seattle, 2005

28. Rao, L, 2014, 'Environmental impact of uncontrolled disposal of ewastes', International Journal of ChemTech Research, vol 6, no. 2, pp. $1343-1353$.

29. Reuter M, Oyi O, Hudson C, Van Schaik A, Heiskanen K, Meskers C et al. Metal recycling: opportunities, limits, infrastructure. A report of the working group on the global metal flows to the international resource panel. In: International Resource Panel WGotGMF, editor. UNEP; 2013.

30. Sahan, M, Kucuker, M, Demirel, B, Kuchta, K and Hursthouse, A 2019, 'Determination of metal content of waste mobile phones and estimation of their recovery potential in Turkey', Environmental Research and Public Health, vol 16, no. 5, via https://www-ncbi-nlmnih-

gov.libraryproxy.griffith.edu.au/pmc/articles/PMC6427248/?tool=pm centrez\&report $=$ abstract

31. Sayman, R and Akpulat, O 2016, 'Regulation on the Control of Waste Electrical and Electronic Equipment, Municipality Implementation Guidance', Regional Environmental Center (REC): Ankara, Turkey, ISBN 978-975-6180-45-7.

32. Scheutz, C, Mosbaek, H, and Kjeldsen, P 2004, 'Attenuation of methane and volatile organic compounds in landfill soil covers, Journal of Environmental Quality, vol 33, no. 1, pp. 61-71, via com.libraryproxy.griffith.edu.au/docview/197371024?pqorigsite $=$ summon

33. Sepulveda, A, Schluep, M, Renaud, F, Streicher, M, Kuehr, R, Hageluken, C, and Gerecke, A 2010, 'A review of the environmental fate and effects of hazardous substances released from electrical and electronic equipments during recycling: examples from China and India' Environmental Impact Assessment Review vol 30, no. 1, pp. 28-41,via org.libraryproxy.griffith.edu.au/10.1016/j.eiar.2009.04.001

34. Sthiannopkao, S and Wong, M 2013, 'Handling e-waste in developed and developing countries: Initiatives, practices, and consequences', The Science of the total environment, vol 463-464, pp. 1147-1153,via https://doi-

org.libraryproxy.griffith.edu.au/10.1016/j.scitotenv.2012.06.088

35. Tanskanen, P 2013, 'Management and recycling of electronic waste', Acta materialia, vol61, no. 3, pp. 1001-1011, via https://doiorg.libraryproxy.griffith.edu.au/10.1016/j.actamat.2012.11.005

36. U.S. Environmental Protection Agency 2003, Particle pollution and your health. EPA-452/F-03-001

37. Wang, H, Han, M, Yang, S, Chen, Y, Liu, Q and Ke, S 2011, 'Urinary heavy metal levels and relevant factors among people exposed to ewaste dismantling', Environment International, vol 37, no. 1, pp. 80 85 , viahttps://doiorg.libraryproxy.griffith.edu.au/10.1016/j.envint.2010.07.005

38. Widmer, R, Krapf, H, Khetriwal, D, Schnellmann, M and Bönia, H 2005, 'Global perspectives on e-waste', Environmental impact assessment review, vol 25, no. 5, pp. 436-458, via: https://doiorg.libraryproxy.griffith.edu.au/10.1016/j.eiar.2005.04.001

39. Zhang, Y, Hou, D, Connor, D, Shen, Z, Shi, P, Ok, Y, Tsang, D, Wen, $\mathrm{Y}$ and Luo, M 2019, 'Lead contamination in Chinese surface soils: Source identification, spatial temporal distribution and associated health risks' Critical reviews in Envuronmental Science and Technology, vol 49, no. 15, pp. 1386-1423, via https://www-scopuscom.libraryproxy.griffith.edu.au/record/display.uri?eid=2-s2.085060864217 \&origin $=$ resultslist\&sort $=$ plf-f\&src $=s \& s t 1=\% 22 \mathrm{e}$ waste $\% 22+\% 22$ land\%22\&st2=\&sid=0adc630866ed7ad344620e6f1c2 3eecd\&sot=b\&sdt=b\&sl=31\&s=TITLE-ABS-KEY\%28\%22ewaste $\% 22+\% 22$ land $\% 22 \% 29 \&$ relpos=2\&citeCnt $=7 \&$ searchTerm=\#

Published By:

Blue Eyes Intelligence Engineering DOI:10.35940/ijmh.F0616.024620

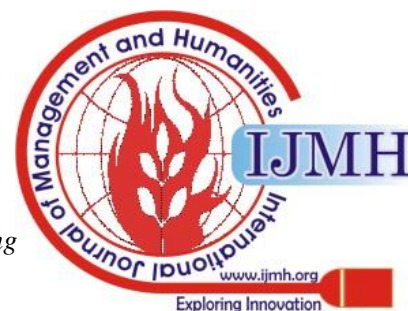




\section{AUTHOR'S PROFILE}

Janet Joseph graduated in Civil Engineering with specialization in Environmental Engineering from Karunya Institute of Technology, Coimbatore, India. Currently pursuing the last trimester of Masters in Environmental Engineering and Pollution Control at Griffith University, Brisbane, Australia. Active member of Engineers Australia Group. Previously published a paper on 'Morphometric Analysis of Mandakini basin using geospatial techniques' an internship done at National Institute of Hydrology, Roorkee, India. Current interest and focus on topics like circular economy, waste management, sustainable energy, cleaner production and eco-efficiency.

LinkedIn: Janet Joseph 